Jahangirnagar University J. Biol. Sci. 8(1): 67-74, 2019 (June)

\title{
Molecular identification and phylogenetic relationships of seven Satyrinae butterflies in Bangladesh using Cytochrome $c$ oxidase subunit I gene
}

\author{
Ananna Ghosh, Muhammad Sohel Abedin, Abdul Jabber Howlader and \\ Md Monwar Hossain* \\ DNA Barcoding Laboratory, Department of Zoology, Jahangirnagar University \\ Savar, Dhaka-1342, Bangladesh
}

\begin{abstract}
The Satyrinae is a subfamily of Nymphalid butterfly, which is morphologically and ecologically the most diverse group, occurring in all habitats. In the present study, Cytochrome $c$ oxidase subunit I (COI) gene of seven species of Satyrinae was sequenced, aligned, and used to construct phylogenetic trees. The molecular identification of these Satyrinae species was confirmed by comparing the related sequences in the National Center for Biotechnology Information (NCBI) GenBank. The base compositions of the COI sequences were $39.07 \% \mathrm{~T}, 16.44 \% \mathrm{C}, 29.83 \% \mathrm{~A}$, and $14.64 \% \mathrm{G}$, revealing a strong AT bias (68.9\%). The sequence distance among Satyrinae species ranged from $0.09 \%$ to $0.18 \%$. Phylogenetic trees were constructed by the neighbor-joining (NJ) and maximum likelihood (ML) methods, using Orthetrum sabina as an outgroup. Both trees had almost identical topologies. The sampled species in Satyrinae exhibited the following relationships: Melanitis leda $+[($ Mycalesis mineus $+($ Mycalesis gotama + Mycalesis anaxias $))+($ Ypthima baldus + (Lethe chandica+Elymnias hypermnestra))], suggesting that $M$. leda might be distantly related with the rest of the Satyrinae species. This clustering result is almost identical to current traditional classification. This study confirms that the COI based DNA barcoding is an efficient method for the identification of butterflies including Satyrinae species and, as such, may further contribute effectively to biodiversity and evolutionary research.
\end{abstract}

Key words: Molecular identification, phylogeny, COI gene, butterfly, Bangladesh

\section{INTRODUCTION}

The Satyrinae is a subfamily of the Nymphalid butterfly which is highly diverse and found worldwide (Murray, 2001). The adults of the most Satyrinae species fly near the ground, preferably in shaded areas of the garden and forest that feeding on fruits in various stages of decomposition and associated fungi (Kremen, 1994; Viloria, 1998; Murray, 2001). The Satyrinae butterflies exhibit special affinity for certain types of vegetation as open areas, primary or secondary forest (De Vries et al., 1997), being considered useful indicators of ecosystem characteristics (Kremen, 1992, 1994; UeharaPrado et al., 2007) and used in population studies (Vila \& Bjorklund, 2004; Schmitt et al., 2005; Besold et al., 2008) and conservation biology (Dennis \& Eales, 1997; Bergman, 1999).

There are about 2,500 described species under the subfamily Satyrinae in the world (Pena \& Wahlberg, 2008). In contrast, IUCN-Bangladesh recorded and assessed 22 species

\footnotetext{
* Corresponding author: E-mail: monwar@juniv.edu
} 
under 6 genera of Satyrinae into threat category (IUCN, 2015). These genera are Mycalesis, Melanitis, Lethe, Ypthima, Orsotriaena and Elymnias. Among the assessed threat category of Satyrinae, 2 species are Data Deficient (DD), 4 are Least Concern (LC), 9 are Vulnerable (VU) and 7 are Endangered (EN) (IUCN, 2015). Although Satyrines are commonly perceived as brown and drab, they are actually diverse in adult coloration. Some are extremely sexually dimorphic and involved in complex mimicry rings (VaneWright, 1971). In addition, seasonal polyphenism that is seasonal variation to response to changes in the environment, is common among butterflies including Satyrinae (Goonesekera et al., 2019). The most prominent seasonal forms are the dry season forms (DSFs) and the wet season forms (WSFs). Each form is characterized by a change in the wing pattern and colouration that optimizes survival during the Dry and Wet Seasons, respectively (Braby, 1994; Roskam \& Brakefield, 1999). Although the morphological variations, different color forms, and other factors are a strategy to increase fitness of these insects, it creates a considerable problem in correct identification (Goonesekeraet al., 2019).

To overcome such problems, a short, standardized 650 bp sequence of the cytochrome $c$ oxidase subunit I (COI) mitochondrial DNA (mtDNA) has been proposed as a barcoding tool, or at least to confirm species delimitation for taxonomic, ecological and evolutionary studies (Hebert et al., 2003; Schindel \& Miller, 2005; Ebach \& Holdrege, 2005; Costa \& Carvalho, 2007; Miller, 2007). Therefore, the present work was carried out to reveal the partial mitochondrial COI gene sequences of the available Satyrinae butterflies of Bangladesh for their species identification, genetic divergence and phylogenetic status.

\section{MATERIALS AND METHODS}

Sample collection: Butterfly specimens were collected from various locations of Bangladesh (Table 1). The specimens were collected by an insect net in the field and preserved by dehydration in a small envelope. Butterflies were identified morphologically by following the keys described in Bingham (1905, 1907), Wynter-Blyth (1957) and Talbot $(1939,1947)$. Voucher specimens were prepared as per Brower (1996).

DNA extraction, amplification and sequencing: Genomic DNA from these seven Satyrinae butterflies were extracted from the legs of adult butterflies according to the protocol of the Wizard Genomic@ DNA Purification Kit (Promega, Madison,WI, USA). PCR amplification of the mitochondrial cytochrome c oxidase I (COI) gene region was performed using the primers LCO 1490 (5'-GGTCAACAAATCATAAAGATATTGG-3') and HCO 2198 (5'-TAAACTTCAGGGTGACCAAAAAATCA-3'). PCR was performed in $20 \mu \mathrm{L}$ of Q2 Green PCR Master Mix (Promega, Madison, WI, USA) in a thermal cycler (Vetteii, USA). The cycle conditions were as follows: initial denaturation $\left(94^{\circ} \mathrm{C}\right.$ for $5 \mathrm{~min}), 35$ cycles of denaturation $\left(94^{\circ} \mathrm{C}\right.$ for $\left.1 \mathrm{~min}\right)$, primer annealing $\left(49^{\circ} \mathrm{C}\right.$ for $\left.1 \mathrm{~min}\right)$, and primer extension $\left(72^{\circ} \mathrm{C}\right.$ for $\left.1 \mathrm{~min}\right)$, and a final extension $\left(72^{\circ} \mathrm{C}\right.$ for $\left.4 \mathrm{~min}\right)$. The success of amplification was evaluated by $1 \%$ agarose gel electrophoresis under ultraviolet light (Bio Analyzer). The amplification product was sequenced using an ABI 3500 sequencer. 
Phylogenetic analysis: The sequences of these seven butterfly species were edited using Chromas version 2.6.2. The assembled sequences were aligned using the ClustalW multiple alignment function in BioEdit version 7.0 (Hall, 1999). Nucleotide compositions were calculated and summarized, and pairwise distances were estimated using the Kimura 2 Parameter (K2P) model with the MEGA10 program (Kimura, 1980; Kumar et al., 2018). Phylogenetic trees were constructed using MEGA10 with the Neighbor-Joining and Maximum likelihood (Saitou \& Nei, 1987; Kumar et al., 2018) methods with 1000 bootstrap replications. Orthetrum sabina from Bangladesh was used in phylogenetic analyses as an outgroup (Table 1).

\section{RESULTS AND DISCUSSION}

The average fragment length of the COI sequences of the seven Satyrinae species was $589 \mathrm{bp}$. The nucleotide sequences were deposited in the National Center for Biotechnology Information (NCBI) GenBank and their accession numbers is given in the Table 1. The sequences were compared with the related sequences of Satyrinae species those were previously deposited in the NCBI's GenBank, and showed 97-100\% similarity, which confirms the accuracy of identification of these Satyrinae species from Bangladesh.

Table 1. Information of species from which $\mathrm{COI}$ genes were sequenced and their GenBank accession numbers

\begin{tabular}{|c|c|c|c|c|}
\hline Species Name & $\begin{array}{c}\text { GPS } \\
\text { coordinates }\end{array}$ & $\begin{array}{c}\text { Date of } \\
\text { collection }\end{array}$ & $\begin{array}{c}\text { Voucher } \\
\text { No. }\end{array}$ & $\begin{array}{c}\text { GenBank } \\
\text { accession No. }\end{array}$ \\
\hline Melanitis leda & $23^{\circ} 52^{\prime} 33 \mathrm{~N} \quad 90^{\circ} 16^{\prime} 6 \mathrm{E}$ & 06-11-2017 & BBV 0300 & MK778434 \\
\hline Mycalesis mineus & $23^{\circ} 52^{\prime} 33 \mathrm{~N} \quad 90^{\circ} 16^{\prime} 6 \mathrm{E}$ & $18-09-2017$ & BBV 0294 & MK778437 \\
\hline Mycalesis gotama & $24^{\circ} 19^{\prime} 44.0^{\prime \prime} \mathrm{N} 91^{\circ} 47^{\prime} 07.6 " \mathrm{E}$ & $11-05-2018$ & BBV 0299 & MK778435 \\
\hline Mycalesis anaxias & $24^{\circ} 19^{\prime} 40^{\prime \prime} \mathrm{N} 91^{\circ} 47^{\prime} 1{ }^{\prime \prime} \mathrm{E}$ & $12-05-2018$ & BBV 0296 & MK757463 \\
\hline Lethe chandica & 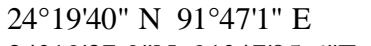 & $11-05-2018$ & BBV 0309 & MK348952 \\
\hline Ypthima baldus & $24^{\circ} 19^{\prime} 37.9^{\prime \prime} \mathrm{N} 91^{\circ} 47^{\prime} 05.6^{\prime \prime} \mathrm{E}$ & $10-05-2018$ & BBV 0286 & MK317934 \\
\hline $\begin{array}{l}\text { Elymnias } \\
\text { hypermnestra }\end{array}$ & $23^{\circ} 52^{\prime} 27.9^{\prime} \mathrm{N} 90^{\circ} 16^{\prime} 05.3^{\prime} \mathrm{E}$ & $18-09-2017$ & BBV 0287 & MH019977 \\
\hline Orthetrum sabina & $23^{\circ} 5221.8 " \mathrm{~N} \quad 90^{\circ} 163.2^{\prime \prime} \mathrm{E}$ & 14-06-2017 & DRBV 029 & MF784360 \\
\hline
\end{tabular}

The $C O I$ gene fragment of 589 bp was analyzed; there were 170 variable sites and 88 parsimony informative sites (Table 2). Most variations occurred at the second and third codon position. Among informative sites, 26 were in the first position and 31 were both in the second and third position (Table 2). The mean base compositions of the COI sequences were $39.07 \% \mathrm{~T}, 16.44 \% \mathrm{C}, 29.83 \% \mathrm{~A}$, and $14.64 \% \mathrm{G}$. There was a strong AT bias $(68.9 \%)$. The $\mathrm{A}+\mathrm{T}$ content of the first, second, and third codon positions of the COI fragment was $89.91 \%, 58.23 \%$ and $58.45 \%$ respectively (Table 2). In general, mitochondrion genome of insects tend to be highly A+T biased (Simon et al., 1994). The above result is in accordance with honey bee mitochondrial genomes (84.9\%), while in Drosophila yakuba this value is $78.6 \%$ (Clary \& Wolstenholme, 1985; Crozier \& Crozier, 1993; Simon et al., 1994). 
Table 2. Basic statistics of the $C O I$ gene sequences of the seven Satyrinae species

\begin{tabular}{|c|c|c|c|c|c|c|c|}
\hline \multirow[t]{2}{*}{ Position } & \multirow{2}{*}{$\begin{array}{c}\text { No. of } \\
\text { sites }\end{array}$} & \multirow{2}{*}{$\begin{array}{c}\text { No. of } \\
\text { variable }\end{array}$} & \multirow{2}{*}{$\begin{array}{c}\text { No. } \\
\text { informative }\end{array}$} & \multicolumn{4}{|c|}{ Empirical base frequencies (\%) } \\
\hline & & & & $\mathrm{T}$ & $\mathrm{C}$ & A & $\mathrm{G}$ \\
\hline All positions & 589 & 170 & 88 & 39.07 & 16.44 & 29.83 & 14.64 \\
\hline First position & 197 & 56 & 26 & 47.86 & 8.55 & 42.05 & 1.5 \\
\hline Second position & 196 & 57 & 31 & 26.53 & 15.08 & 31.70 & 26.67 \\
\hline Third position & 196 & 57 & 31 & 42.78 & 25.72 & 15.67 & 15.81 \\
\hline
\end{tabular}

The pairwise distance was calculated by the MEGA10 program. The interspecific nucleotide divergence among the seven species ranged from $0.09 \%$ to $0.18 \%$ (Table 3 ). The highest distance of $0.18 \%$ was obtained between Mycalesis gotama and Melanitis leda. The shortest distance of $0.09 \%$ was obtained between Mycalesis gotama and Mycalesis minus. This result is consistent with the finding of Zakharov et al. (2004) where the sequence divergences ranged from $0 \%$ to $1.2 \%$ for many Papilio species. This low range of interspecific divergence may be observed due to the presence of interspecies hybridization, which is a familiar phenomenon in many butterflies (Win et al., 2015).

Table. 3. Percentage pairwise distances among seven Satyrinae species

\begin{tabular}{l|c|c|c|c|c|c}
\hline \multicolumn{1}{c}{ Species Name } & $\mathbf{1}$ & $\mathbf{2}$ & $\mathbf{3}$ & $\mathbf{4}$ & $\mathbf{5}$ & $\mathbf{6}$ \\
\hline $\begin{array}{l}\text { Melanitis leda } \\
\text { Mycalesis mineus }\end{array}$ & 0.13 & & & & & \\
Mycalesis gotama & 0.18 & 0.09 & & & & \\
Mycalesis anaxias & 0.17 & 0.11 & 0.11 & & & \\
Lethe chandica & 0.16 & 0.11 & 0.14 & 0.14 & & \\
Ypthima baldus & 0.17 & 0.13 & 0.15 & 0.17 & 0.15 & \\
Elymnias hypermnestra & 0.15 & 0.11 & 0.13 & 0.14 & 0.11 & 0.14 \\
\hline
\end{tabular}

The phylogenetic trees for the COI gene constructed using the NJ and ML methods showed approximately identical clustering (Fig. 1, Fig. 2). Orthetrum sabina was used as an outgroup, and both of the $\mathrm{NJ}$ and $\mathrm{ML}$ trees revealed two main Clades, A and B. Clade A consisted of 3 species of one genera (Mycalesis) viz. M. mineus, M. gotama and M. anaxias and Clade B consisted of three species of three genera viz. Ypthima baldus, Lethe chandica and Elymnias hypermnestra.

In Clade A, the genus Mycalesis shows a strongly supported monophyletic group in NJ tree and a well-supported monophyletic group in ML tree. M. mineus is a sister group to $M$. gotama and $M$. anaxias with strong support in NJ and a well-supported in ML tree. The relationships of species in Mycalesis in Clade A are as follows: [Mycalesis mineus+(Mycalesis gotama+Mycalesis anaxias)] (Fig. 1, Fig. 2). 


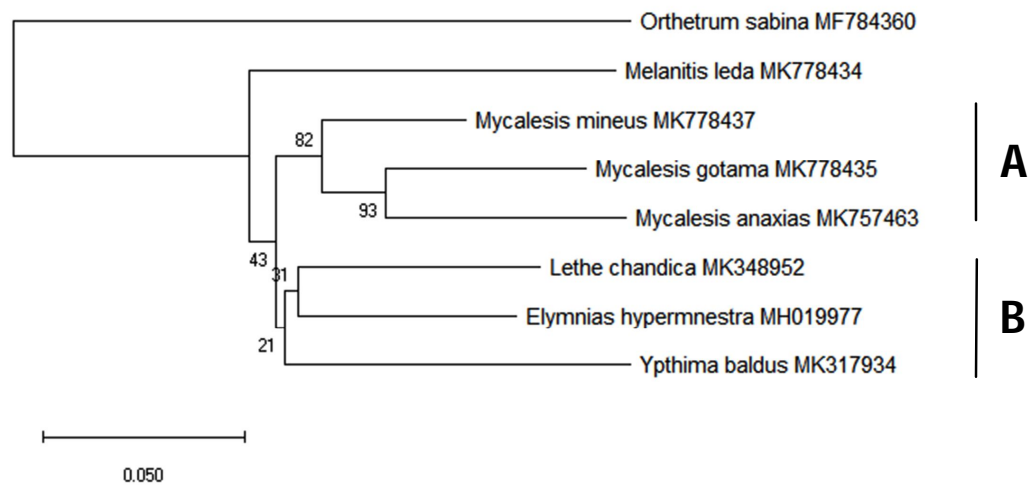

Fig. 1. Neighbor-Joining (NJ) tree of the Satyrinae butterflies based on COI gene sequences. Bootstrap values are shown at the branching points. $O$. sabina was used as the outgroup

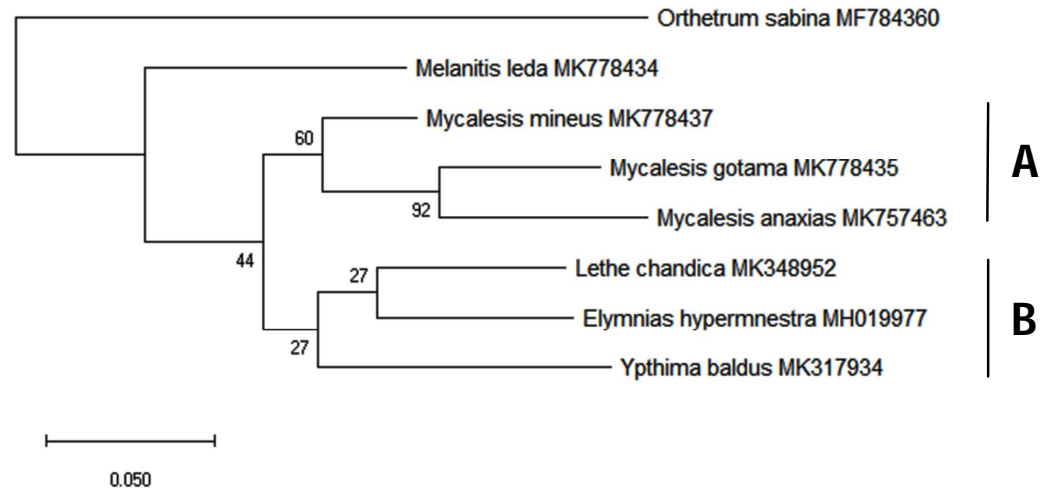

Fig. 2. Maximum Likelihood (ML) tree of the Satyrinae butterflies based on COI gene sequences. Bootstrap values are shown at the branching points. $O$. sabina was used as the outgroup

In Clade B, Ypthima baldus is resoled as a sister group to Lethe chandica and Elymnias hypermnestra as well as forms a monophyletic group with very weak support in NJ and ML trees. In Clade B, the relationships among species are as follows: [Ypthima baldus+(Lethe chandica+Elymnias hypermnestra)] (Fig. 1, Fig. 2). M. leda is resoled as a sister to the A and B Clade indicating that M. leda might have distant relationship with the Satyrinae species of Clade A and B (Fig. 1 and Fig. 2). These findings are in accordance with the finding of Yang et al. (2015), and also supported by the traditional classification method. Moreover, the DNA barcode generated in the present study will be available through GenBank to researchers for the species identifications and, as such, may further contribute effectively to biodiversity and evolutionary research. 
Acknowledgements: The authors gratefully acknowledge the financial support from the project: "Enhancement of Entomological Research Capability Using DNA Barcoding", University Grants Commission of Bangladesh (CP No. 3424).

\section{REFERENCES}

Bingham, C.T. 1905. Fauna of British India. Butterflies, Vol. I. Taylor and Francis, London. 1511.

Bingham, C.T.1907. Fauna of British India. Butterflies, Vol. II. Taylor and Francis, London. 1480.

Bergman, K-O. 1999. Habitat utilization by Lopinga achine (Nymphalidae:Satyrinae) larvae and ovipositing females: implications for conservation. Biol Conserv. 88: 69-74.

Besold, J., Huck, S. and Schmitt, T. 2008. Allozyme polymorphisms in the small heath, Coenonympha pamphilus: recent ecological selection or biogeographical signal?. Ann Zool Fenn. 45: 217-228.

Braby, M.F. 1994. Phenotypic variation in adult Mycalesis Hubner (Lepidoptera:Nymphalidae: Satyrinae) from the Australian wet-dry tropics. Journal of Australian Entomological Society. 33: 327-336.

Brower, A.V.Z. 1996. A new mimetic species of Heliconius (Lepidoptera:Nymphalidae), from southeastern Colombia, as revealed by cladistic analysis of mitochondrial DNA sequences. Zoological Journal of the Linnean Society. 116: 317-332.

Clary, D.O. and Wolstenholme, D.R. 1985. The mitochondrial DNA molecule of Drosophila yakuba: Nucleotide sequence, gene organization, and genetic code. Journal of Molecular Evolution. 22(3): 252-271.

Crozier, R.H. and Crozier, Y.C. 1993. The mitochondrial genome of the honeybee Apis mellifera: complete sequence and genome organization. Genetics. 133(1): 97-117.

Costa, F.O. and Carvalho, G.R. 2007. The Barcode of Life Initiative: synopsis and prospective societal impacts of DNA barcoding of Fish. Genomics, society, and policy / ESRC Genomics Network. 3:29-40.

Dennis, R.L.H. and Eales, H.T. 1997. Patch occupancy in Coenonympha tullia (Muller, 1764) (Lepidoptera:Satyrinae): habitat quality matters as much as patch size and isolation. J Insect Conserv. 1: 167-176.

DeVries, P.J., Murray, D. and Lande, R. 1997. Species diversity in vertical, horizontal, and temporal dimensions of a fruit-feeing butterfly community in an Ecuadorian rainforest. Biological Journal of the Linnean Society. 62: 343-364.

Ebach, M.C. and Holdrege, C. 2005. DNA barcoding is no substitute for taxonomy. Nature. 7: 434(7034):697.

Goonesekeraa, K., Leeb, P.L.M., Poortenc, G.V. and Ranawaka, G.R. 2019. The phylogenetic history of the old world butterfly subtribe Mycalesina extended: the Mycalesis (Lepidoptera: Nymphalidae) of SriLanka. Journal of Asia-Pacific Entomology. 22(1): 121-133.

Hall, T.A. 1999. Bioedit, a user-friendly biological sequences alignment editor and analysis program for windows95/98/NT. Nucleic Acids Symposium Ser. 41: 95-98.

Hebert, P.D.N., Cywinska, A., Ball, S.L. and deWaard, J.R. 2003. Biological identifications through DNA barcodes. Proc. R. Soc. Lond. B. 270: 313-321.

IUCN-Bangladesh. 2015. Red List of Bangladesh. Vol. 7: Butterflies. IUCN, International Union for Conservation of Nature, Bangladesh Country Office, Dhaka, Bangladesh. pp 1-400.

Kimura, M. 1980. A simple method for estimating evolutionary rate of base substitutions through comparative studies of nucleotide sequences. Journal of Molecular Evolution. 16: 111-120. 
Molecular identification, phylogenetic relationships, butterflies, COI gene

Kremen, C. 1992. Assessing the indicator properties of species assemblages for natural areas monitoring. Ecol Appl. 2: 203-217.

Kremen, C. 1994. Biological inventory using target taxa: a case study of the butterflies of Madagascar. Ecol Appl. 4: 407-422.

Kumar, S., Stecher, G., Li, M., Knyaz, C. and Tamura, K. 2018. MEGA X: Molecular Evolutionary Genetics Analysis across computing platforms. Molecular Biology and Evolution. 35: 1547-1549.

Miller, S.E. 2007. DNA barcoding and the renaissance of taxonomy. PNAS. 104(12):4775-4776.

Murray, D.L. and Prowell, D.P. 2005. Molecular phylogenetics and evolutionary history of the neotropical Satyrine Subtribe Euptychiina (Nymphalidae:Satyrinae). Molecular Phylogenetics and Evolution. 34: 67-80.

Murray, D.L. 2001. Systematics of Neotropical satyrine butterflies (Nymphalidae:Satyrinae: Euptychiina) based on larval morphology and DNA sequence data and the evolution of life history traits. PhD Thesis, Louisiana State University, Baton Rouge, Louisiana.

Peña, C. and Wahlberg, N. 2008. Prehistorical climate change increased diversification of a group of butterflies. Biol Lett. 4: 274-278.

Roskam, J.C. and Brakefield, P.M. 1999. Seasonal polyphenism in Bicyclus (Lepidoptera: Satyridae) butterflies: different climates need different cues. Biological Journal of the Linnean Society. 66: 345-356.

Saitou, N. and Nei, M. 1987. The neighbor-joining method: A new method for reconstructing phylogenetic trees. Molecular Biology and Evolution. 4: 406-425.

Schindel, D.E. and Miller, S.E. 2005. DNA barcoding a useful tool for taxonomists. Nature. 5: 435(7038): 17.

Schmitt, T., Cizek, O. and Konvicka, M. 2005. Genetics of a butterfly relocation: large, small and introduced populations of the mountain endemic Erebia epiphron silesiana. Biol Conserv. 123: $11-18$.

Simon, C., Frati, F., Beckenbach, A., Crespi, B., Liu, H. and Flook, P. 1994. Evolution, weighting, and phylogenetic utility of mitochondrial gene sequences and a compilation of conserved polymerase chain reaction primers. Annals of the Entomological Society of America. 87: 651-701.

Talbot, G. 1939. The Fauna of British India including Ceylon and Burma. Butterflies. Vol. I. Taylor \& Francis, London (Reprinted by Today and Tomorrow's Printers and Publishers, New Delhi). xxix+600.

Talbot, G. 1947. The Fauna of British India including Ceylon and Burma. Butterflies. Vol. II. Taylor \& Francis, London (Reprinted by Today and Tomorrow's Printers and Publishers, New Delhi); xv+506.

Uehara-Prado, M., Brown, Jr K.S. and Freitas, A.V.L. 2007. Species richness, composition and abundance of fruit-feeding butterflies in the Brazilian Atlantic Forest: comparison between a fragmented and a continuous landscape. Glob Ecol Biogeogr. 16: 43-54.

Vila, M. and Björklund, M. 2004. Testing biennialism in the butterfly Erebia palarica (Nymphalidae: Satyrinae) by mtDNA sequencing. Insect Mol Biol. 13: 213-217.

Vane-Wright, R.I. 1971. The systematics of Drusillopsis Oberthur (Satyrinae) and the supposed Amathusiid Bigaena van Eecke (Lepidoptera:Nymphalidae, with some observations on Batesian mimicry. J. Trans R Entomol Soc Lond. 123: 97-123.

Viloria, A.L. 1998. Studies on the Systematics and Biogeography of some MontaneSatyrid Butterflies (Lepidoptera). Ph.D. thesis. London, University of London. 493.

Wynter-Blyth, M.A. 1957. Butterflies of the Indian Region. Bombay Natural History Society, Bombay. 1-523. 
Win, N.Z.,Choi, E.Y., Jang, D-J., Park, J. and Park, J.K. 2015. Molecular comparison of the genus Junonia (Lepidoptera: Nymphalidae) in Myanmar. Journal of Asia-Pacific Biodiversity. 8(4): 287-294.

Yang, M., Zhai, Q., Yang, Z. and Zhang, Y. 2015. DNA barcoding Satyrine butterflies (Lepidoptera:Nymphalidae) in China. Mitochondrial DNA, Early Online. 1-6.

Zakharov, E.V., Caterino, M.S. and Sperling, F.A.H. 2004. Molecular phylogeny, historical biogeography, and divergence time estimates for swallowtail butterflies of the genus Papilio (Lepidoptera:Papilionidae). Systematic Biology. 53: 193-215. 